\title{
Strategi Pengembangan Industri Kreatif Produk Sulam Tempel Bordir Di Desa Seritanjung Ogan Ilir
}

\author{
Ninin Non Ayu Salmah ${ }^{1}$, Emma Lilianti ${ }^{2}$ \\ ${ }^{1}$ Manajemen, Fakultas Ekonomi, Univ.PGRI Palembang, nininsalmah@univpgri-palembang.ac.id \\ ${ }^{2}$ Manajemen, Fakultas Ekonomi, Univ. PGRI Palembang, emmaliliantie@univpgri-palembang.ac.id
}

\begin{abstract}
ABSTRAK
Tujuan penelitian ini adalah untuk menganalisis kekuatan, kelemahan, peluang dan tantangan yang dihadapi industri kreatif produk sulam tempel bordir di Desa Seritanjung Ogan llir serta menentukan strategi yang tepat dalam upaya mengembangkan industri kreatif produk sulam tempel bordir di Desa Seritanjung Ogan llir. Penelitian ini menggunakan data primer dengan teknik pengumpulan data observasi wawancara. Keabsahan data adalah metode triangulasi sumber. Variabel penelitian adalah profil usaha industri kreatif sulam tempel bordir di Desa Seritanjung. Metode analisis data adalah deskriptif dengan pendekatan kualitatif. Teknik analisis data dalam penelitian ini adalah menyusun matriks IFE dan EFE, analisis matriks SWOT, analisis grafik cartesius dan analisis kombinasi strategi kuantitatif. Penelitian ini menghasilkan usulan strategi yang tepat untuk mengembangkan industri kreatif sulam tempel bordir di Desa Seritanjung adalah strategi SO (strength-opportunities).
\end{abstract}

Keywords : industri kreatif, analisis SWOT, strategi

\section{PENDAHULUAN}

Industri konvensional yang mengolah bahan baku dan berasal dari sumber daya alam selama ini menjadi komponen pertumbuhan perekonomian nasional. Beberapa tahun ini, perkembangan sektor industri kreatif yang merupakan sektor industri kecil dan menengah juga menunjukkan tren positif dan turut mendukung pertumbuhan perekonomian nasional. Industri kreatif berkembang karena adanya ide, ketrampilan dan bakat dari pelaku industri kreatif.

Industri kreatif dapat membuka peluang usaha baru karena hakikatnya kreatifitas adalah kemampuan untuk memperoleh ide atau gagasan yang baru yang diterjemahkan dalam bentuk inovasi sehingga diperoleh direalisasikan dalam produk yang baru. Dengan demikian industri kreatif dapat mebuka peluang usaha yang baru karena adanya produk baru sebagai hasil dari proses kreatifitas. Akibat dari dari proses kreatifitas tersebut maka tercipta beragam produk yang dapat memenuhi ekspektasi konsumen. Industri kreatif juga menyerap tenaga kerja karena penggunaan tenaga kerja dalam menghasilkan produk tergantung pada kemampuan dan kompetensinya secara individu.

Pelaku industri kreatif dapat mengangkat kekhasan atau keunggulan suatu daerah melalui penggalian ide, pengalaman dan pembelajaran terhadap budaya sehingga dapat melestarikan budaya. Produk tersebut dapat memperkenalkan Indonesia kepada dunia luar dan menjadi penghasil devisa negara.

Siklus hidup produk industri kreatif cukup singkat karena adanya imitator yang meniru produk yang baru, walaupun demikian produk yang ditiru tersebut akan kembali mengalami proses kreatifitas sehingga produk tersebut lebih berkembang dan mengalami penyempurnaan secara berkelanjutan sehingga beragam. Margin yang diperoleh biasanya cukup tinggi karena diproduksi dalam jumlah relatif kecil. 
Industri kecil dan menengah dengan mengandalkan ketrampilan berkembang di Kecamatan Tanjung Batu Kabupaten Ogan Ilir. Hampir setiap desa di Kecamatan tanjung Batu memiliki produk yang dibuat dengan keterampilan dan produk yang dihasilkan tiap desa berbeda. Industri kreatif di Kecamatan Tanjung Batu berkembang dengan dukungan keterampilan khas yang dimiliki masyarakat secara turun-temurun didukung kedekatan lokasi dengan Kota Palembang sebagai lbukota Propinsi yang dapat membuka akses pemasaran di wilayah lainnya.

Sentra produksi kerajinan khas masyarakat Kecamatan Tanjung Batu diantaranya kerajinan perhiasan emas dan perak dari Desa Tanjung Batu atau tenun songket dari Desa Limbang Jaya. Salah satu desa di Kecamatan Tanjung Batu Ogan llir adalah Desa Seritanjung. Pada tahun 1990-an sampai dengan 2000-an Desa Seritanjung terkenal dengan kerajinan sulam tempel bordir dengan produk berupa sprei, sarung bantal, taplak meja makan dan taplak meja tamu. Seiring berkembangnya produksi massa sehingga harga jual produk sejenis relatif kompetitif maka jumlah produksi produk sulam tempel bordir yang membutuhkan ketrampilan individu menurun. Dalam situasi persaingan tersebut, saat ini hanya tinggal beberapa orang yang memiliki keterampilan sulam tempel dan bordir dan masih terdapat 2 pelaku usaha saja yang berwirausaha di bidang sulam tempel dan bordir.

Hubungan wirausahawan dan perajin produk sulam tempel bordir merupakan mitra kerja yang memberikan sebagian pekerjaannya kepada perajin. Bahan baku dan pemasaran menjadi tanggung jawab wirausahawan sedangkan bahan penolong untuk membuat sulam tempel dan bordir serta fasilitas produksi menjadi tanggung jawab perajin.

Upaya untuk membangkitkan kerajinan sulam tempel bordir yang pernah menjadi produk unggulan Desa Seritanjung dan sumber pendapatan masyarakat memerlukan suatu strategi. Strategi tersebut didahului dengan melakukan analisis mengenai kekuatan, kelemahan sebagai analisis faktor internal dan analisis peluang dan tantangan sebagai analisis faktor eksternal usaha atau dikenal dengan analisis SWOT sehingga dapat menggambarkan kemampuan pelaku usaha dan perajin dalam mengalokasikan sumber daya dan mengoptimalkan sumber daya tersebut untuk memanfaatkan peluang dan menghadapi tantangan dalam berusaha. Tujuan penelitian ini adalah untuk menganalisis kekuatan, kelemahan, peluang dan tantangan yang dihadapi industri kreatif produk sulam tempel bordir di Desa Seritanjung Ogan Ilir serta menentukan strategi yang tepat dalam upaya mengembangkan industri kreatif produk sulam tempel bordir di Desa Seritanjung Ogan Ilir.

\section{LANDASAN TEORI Industri Kreatif}

Nilai tambah yang diperoleh dari suatu industri mendukung pertumbuhan perekonomian sehingga membawa kesejahteraan masyarkat. Nilai tambah diperoleh melalui proses produksi atau operasi dalam suatu industri. Industri mengubah sumber daya baik sumber daya manusia maupun sumber daya alam menjadi lebih bernilai tambah baik bentuk, kepemilikan maupun penggunaannya. Industri merupakan suatu kegiatan ekonomi yang mengolah barang mentah, bahan baku, barang setengah jadi atau barang jadi untuk dijadikan 
barang yang lebih tinggi kegunaannya (Sukirno, 2010:54).

Kegiatan ekonomi dimaksudkan untuk menghubungan pihak produsen hingga ke pelanggan. Permintaan terhadap produk ditentukan oleh kemampuan produsen atau pemasar menerjemahkan ide-ide kreatifnya dalam produk. Kreatif berhubungan dengan kegiatan manusia yang dilandasi oleh sikap mental yang selalu ingin menghasilkan ide-ide baru yang didasari oleh sebuah konsep keindahan (Kamil, 2015). Ide atau gagasan diterjemahkan dalam bentuk produk sehingga produk tersebut dapat bersaing dan memberikan pendapatan.

Produk yang dihasilkan ekonomi kreatif atau industri kreatif membutuhkan kemampuan individu karena produk yang dihasilkan dari industri tersebut mengandung kekhasan tertentu. Industri kreatif didefinisikan sebagai industri yang berasal dari pemanfaatan kreativitas, keterampilan serta bakat individu untuk menciptakan kesejahteraan serta lapangan pekerjaan dengan menghasilkan dan memberdayakan daya kreasi dan daya cipta individu tersebut (Kementerian Perdagangan, 2008: 10).

\section{Sektor Industri Kreatif}

Kementerian

(2008:4) juga mengidentifikasi setidaknya 14 sektor yang termasuk dalam ekonomi kreatif, yaitu periklanan, arsitektur, pasar barang seni, kerajinan (handicraft), desain, fashion, film, video, dan fotografi, permainan interaktif,musik, seni pertunjukan, penerbitan dan percetakan, layanan komputer dan piranti lunak, radio dan televisi serta riset dan pengembangan. Dengan adanya sektor-sektor tersebut diharapkan masyarakat pelaku ekonomi kreatif dapat mengembangkan kreativitasnya sehingga suasana ekonomi produktif menjangkau individu yang memiliki keterampilan atau talenta tertentu.

Pemerintah melalui Kementerian Perdagangan (2008:15) membuat arah pengembangan industri kreatif yaitu seperti pengembangan yang lebih menitikberatkan pada industri berbasis lapangan usaha kreatif dan budaya (creative cultural industry), lapangan usaha kreatif (creative industry), Hak Kekayaan Intelektual seperti hak cipta (copyright industry). Arah pengembangan tersebut memungkinkan industri kreatif sebagai bagian dari industri kecil dan menengah berkembang searah dengan perkembangan industri konvensional.

\section{Strategi}

Suatu usaha didirikan didasari sebuah misi yang diperinci menjadi sasaran atau tujuan. Pencapaian sasaran dilakukan melalui penerapan strategi. Tjiptono (2008:3) mendefinisikan strategi sebagai sebagai program untuk menentukan dan mencapai tujuan organisasi.

Manajemen mengambil keputusan yang ditujukan pada pencapaian tujuan berdasarkan strategi yang telah dibuat. Strategi membentuk pola pengambilan keputusan dalam mewujudkan visi organisasi (Handriani, 2011). Strategi harus dirumuskan dengan jelas karena para pengambilan keputusan akan selalu berpedoman pada strategi yang akan diterapkan sehingga tujuan tercapai secara efektif.

\section{Analisis SWOT}

Kegiatan yang paling penting dalam proses analisis SWOT adalah memahami seluruh informasi dalam suatu kasus, menganalisis situasi untuk mengetahui isu apa yang 
sedang terjadi dan memutuskan apa yang harus segera dilakukan untuk memecahkan masalah (Rangkuti, 2008:14). Analisis SWOT digunakan untuk mengidentifikasi dan evaluasi faktor internal yaitu kekuatan (strenght) dan kelemahan (weakness) serta faktor eksternal usaha yaitu peluang (opportunity) dan ancaman (threats), untuk selanjutnya dapat diambil keputusan yang berkenaan dengan pengembangan usaha di masa mendatang.

Siagian (2005:172) menjelaskan mengenai faktor internal dan eksternal yaitu 1)Kekuatan yaitu faktor- faktor kekuatan yang dimiliki oleh perusahaan termasuk satuan bisnis di dalamnya adalah antara lain kompetensi khusus yang terdapat dalam organisasi yang berakibat pada pemilikan keunggulan komparatif oleh unit usaha di pasaran 2)Kelemahan yaitu keterbatasan atau kekurangan dalam hal sumber, keterampilan dan kemampuan yang menjadi penghalang serius bagi penampilan kinerjaorganisasi yang memuaskan 3)Peluang, yaitu berbagai situasi lingkungan yang menguntungkan bagi suatu satuan bisnis 4)Ancaman yaitu faktor- faktor lingkungan yang tidak menguntungkan suatu satuan bisnis.

\section{Analisis Faktor Internal dan Eksternal}

Analisis faktor internal dan eksternal berguna untuk mengumpulkan data. Alat analisis yang digunakan adalah Matriks EFE (Eksternal Faktors Evaluation) dan Matriks IFE (Internal Factors Evaluation). Matriks EFE adalah alat analisis yang digunakan untuk merumuskan faktor-faktor eksternal perusahaan yang meliputi peluang serta ancaman yang berasal dari lingkungan eksternal perusahaan dan Matriks IFE adalah alat analisis yang digunakan untuk merumuskan faktorfaktor internal perusahaan yang meliputi kekuatan (strength) dan kelemahan (weakness) yang berasal dari lingkungan internal perusahaan (Umar dalam Saputro,dkk, 2016).

Rangkuti

(2008:24-26) menjelaskan analisis faktor internal dan eksternal dalam bentuk tabel berikut ini.

\begin{tabular}{|l|l|l|l|}
\hline \multicolumn{1}{|c|}{ Faktor Internal \& Eksternal } & Bobot & Rating & Bobot x Rating \\
\hline Kekuatan & & & \\
\hline Kelemahan & & & \\
\hline Peluang & & & \\
\hline Ancaman & & & \\
\hline
\end{tabular}

Penilaian faktor internal dan eksternal dalam bentuk matriks EFE dan IFE dilakukan dengan memberi bobot dan rating pada masing-masing faktor yang dievaluasi. Pemberian bobot masing-masing skala mulai dari 1,0 (paling penting) sampai 0,0 (paling tidak penting). Total bobot tidak boleh melebihi skor 1,00. Pemberian rating skala mulai dari 4 sampai dengan 1 berdasarkan pengaruh faktor terhadap kondisi yang ada. Pemberian nilai rating untuk faktor kekuatan dan pelaung yang bersifat positif semakin besar diberi rating 4 tetapi bila kecil diberi rating 1 . Pemberian nilai rating kelemahan dan ancaman yang bersifat negatif semakin besar diberi rating 1 tetapi bila kecil diberi rating 4 (Gunawan dan Permadi, 2015).

\section{Matriks Analisis SWOT}

Matriks analisis SWOT digunakan setelah diperoleh informasi 
mengenai faktor internal yang dimiliki dan eksternal yang dihadapi. Alat yang dipakai untuk menyusun faktor-faktor strategis perusahaan adalah matrik SWOT, matrik SWOT mengambarkan bagaimana peluang dan ancaman eksternal yang dihadapi perusahaan yang disesuaikan dengan kekuatan dan kelemahan yang dimilikinya (Nisak, 2013). Rangkuti (2008:31) menggambarkan matriks analisis SWOT sebagai berikut :

\begin{tabular}{|l|l|l|}
\hline \multirow{2}{*}{ Eksternal } & \multicolumn{2}{|c|}{ Internal } \\
\cline { 2 - 3 } O (Opportunities) & $\begin{array}{c}|c| \\
\text { Strategi SO W (Strenght) } \\
\text { Ciptakan strategi yang } \\
\text { menggunakan kekuatan untuk } \\
\text { memanfaatkan peluang }\end{array}$ & $\begin{array}{l}\text { Strategi WO } \\
\text { Ciptakan strategi yang } \\
\text { meminimalkan kelemahan } \\
\text { untuk memanfaatkan peluang }\end{array}$ \\
\hline T (Threats) & $\begin{array}{l}\text { Strategi ST strategi yang } \\
\text { Ciptakan } \\
\text { menggunakan kekuatan untuk } \\
\text { mengatasi ancaman }\end{array}$ & $\begin{array}{l}\text { Strategi WT } \\
\text { Ciptakan strategi yang } \\
\text { meminimalkan kelemahan } \\
\text { dan menghindari ancaman }\end{array}$ \\
\hline
\end{tabular}

Rangkuti

(2008:31-32)

menjelaskan strategi yang dihasilkan dari matriks analisis SWOT adalah strategi SO, ST, WO dan WT. Strategi SO dibuat berdasarkan jalan pikiran memanfaatkan seluruh kekuatan untuk merebut dan memanfaatkan peluang sebesar-besarnya. Strategi ST adalah strategi dalam menggunakan kekuatan yang dimiliki untuk mengatasi ancaman. Strategi WO diterapkan berdasarkan pemanfaatan peluang yang ada dengan cara meminimalkan kelemahan yang ada. Strategi WT didasarkan pada kegiatan usaha meminimalkan kelemahan yang ada serta menghindari ancaman.

Diagram

kartesius menggambarkan bagaimana faktor eksternal disesuaikan dengan faktor internal.peluang dan ancaman Rangkuti (2008:20) menggambarkan grafik kartesius berikut ini.

\section{Peluang}

Mendukung strategi arround, Mendukung strategi growth

Kelemahan

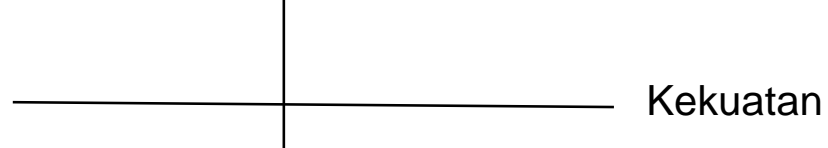

Mendukung strategi defensif Mendukung strategi diversification

Ancaman $(0,8)$ 
Pada kuadran 1 strategi yang diterapkan adalah mendukung kebijakan pertumbuhan, pada kuadran 2 strategi yang diterapkan adalah mengunakan kekuatan untuk memanfaatkan peluang jangka panjang dengan cara strategi diversifikasi, pada kuadran 3 strategi adalah meminimalkan masalah internal sehingga dapat merebut peluang pasar yang baik dan pada kuadran 4 menghadapi berbagai ancaman dan kelemahan internal.

\section{Metode Penelitian}

Penelitian ini menggunakan data primer yaitu data yang diperoleh secara langsung dari obyek penelitian. Data penelitian diperoleh menggunakan teknik pengumpulan data yaitu 1)observasi yaitu dengan melakukan pengamatan langsung pada pelaku dan para perajin sulam tempel bordir di Desa Seritanjung 2)wawancara yaitu dengan melakukan tanya jawab dengan pelaku dan para perajin sulam tempel bordir di Desa Seritanjung. Wawancara dilakukan dengan berdasarkan pedoman wawancara sebagai instrumen penelitian. Keabsahan data dilakukan dengan metode triangulasi sumber (Moleong, 2013:330-332) yaitu membandingkan data hasil observasi dengan hasil wawancara, perspektif narasumber wawancara dengan keadaan real di lapangan. Variabel penelitian adalah profil usaha industri kreatif sulam tempel bordir di Desa Seritanjung dengan indikator keterampilan tenaga kerja, minat kewirausahaan, desain produk, lini, bahan baku, area atau tempat pemasaran dan program pemasaran, kebijakan pemerintan dan jaringan permodalan.

Metode analisis data dalam penelitan ini adalah deskriptif dengan pendekatan kualitatif. Metode penelitian kualitatif adalah metode penelitian yang berlandaskan pada filsafat postpositivisme yang digunakan untuk meneliti pada kondisi objek yang alamiah (sebagai lawannya adalah ekperimen) dimana peneliti adalah sebagai instrumen kunci, teknik pengumpulan data dilakukan secara triangulasi (gabungan), analisis data bersifat induktif atau kualitatif, dan hasil penelitian kualitatif lebih menekankan makna daripada generalisasi (sugiyono, 2008:9). Metode penelitian deskriptif pada penelitian ini adalah dengan mengidentifikasi, merumuskan dan menafsirkan data sehingga dapat diperoleh gambaran mengenai profil industri kreatif produk sulam tempel bordir di Desa Seritanjung.

Teknik analisis data dalam penelitian ini adalah menyusun dan menganalisis matriks IFE dan EFE dilanjutkan matriks SWOT (Ayuningtyas dan Djoeffan, 2010). Penyusunan dan analisis matrik SWOT dilanjutkan dengan menggambar dan menganalisis diagram kartesius serta menyusun dan menganalisis tabel kombinasi strategi kuantitatif (Anggraeni, dkk, 2017). Matriks IFE disusun untuk menganalisis lingkungan internal sehingga diperoleh identifikasi dan perumusan berbagai kemungkinan kekuatan dan kelemahan dalam industri sedangkan matriks EFE disusun untuk menganalisis lingkungan eksternal sehingga diperoleh identifikasi dan perumusan berbagai kemungkinan peluang yang dapat dimanfaatkan dan ancaman yang dihadapi industri. Dalam penyusunan kedua tabel tersebut dilakukan pembobotan dan penilaian rating. Analisis matriks SWOT adalah matriks yang menginteraksikan faktor strategis internal dan eksternal dengan menggambarkan bagaimana peluang 
dan ancaman yang dihadapi dapat disesuaikan dengan kekuatan dan kelemahan. Diagram kartesius dan tabel kombinasi strategi kuantitatif digunakan untuk menentukan strategi yang tepat dalam pengembangan industri kreatif sulam tempel bordir di Desa Seritanjung.

\section{PEMBAHASAN \\ Analisis Matriks IFE \& EFE}

Matriks IFE merupakan sarana analisis faktor internal yang dapat dikendalikan. Identifikasi faktor kekuatan dan kelemahan industri kreatif produk sulam tempel bordir Desa Seritanjung disajikan pada matriks IFE berikut ini.

\begin{tabular}{|c|c|c|c|}
\hline Faktor & Bobot & Rating & $\begin{array}{l}\text { Bobot } x \\
\text { Rating }\end{array}$ \\
\hline \multicolumn{4}{|l|}{ Kekuatan } \\
\hline 1.Tenaga kerja trampil & 0,20 & 4 & 0,80 \\
\hline 2.Produk unggulan & 0,10 & 3 & 0,30 \\
\hline 3.Harga per unit & 0,05 & 2 & 0,30 \\
\hline 4.Kebutuhan modal & 0,05 & 2 & 0,30 \\
\hline Subtotal & 0,40 & & 1,70 \\
\hline \multicolumn{4}{|l|}{ Kelemahan } \\
\hline 1.Kreatifitas dan inovasi & 0,20 & 2 & 0,10 \\
\hline 2.Pengetahuan wirausaha & 0,20 & 2 & 0,10 \\
\hline 3.Program pemasaran & 0,20 & 2 & 0,40 \\
\hline Subtotal & 0,60 & & 0,80 \\
\hline Total & 1,00 & & 2,50 \\
\hline
\end{tabular}

Analisis faktor kekuatan yang dimiliki industri kreatif produk sulam tempel bordir Desa Seritanjung adalah ketersediaan tenaga kerja yang terampil membuat produk sulam tempel bordir, produk sulam tempel bordir pernah menjadi produk unggulan dan khas dari Desa Seritanjung, harga per unit produk relatif murah dan kebutuhan modal untuk produksi relatif rendah. Ibu-ibu rumah tangga baik yang berusia lanjut maupun ibu-ibu muda di Desa Seritanjung merupakan tenaga kerja yang terampil dalam membuat produk sulam tempel dan bordir, pada saat ini masih terdapat 12 orang ibu rumah tangga yang menjadi perajin produk sulam tempel bordir. Produk sulam tempel bordir pernah menjadi produk unggulan dan khas dari Desa Seritanjung yang mendukung perekonomian keluarga sehingga apabila diberikan motivasi dan ditanamkan kesadaran kepada masyarakat Desa Seritanjung diharapkan akan menjadi masyarakat yang produktif. Harga per unit produk relatif rendah karena upah yang diberikan pengusaha kepada perajin cukup rendah karena memang pembuatan produk tersebut termasuk relatif mudah dengan biaya produksi yang rendah. Modal yang dibutuhkan untuk membuat produk sulam tempel dan bordir relatif rendah karena pengusaha hanya menanggung biaya bahan baku utama yaitu kain dan biaya pemasaran sedangkan biaya bahan penolong dan fasilitas produksi disediakan oleh perajin.

Analisis faktor kelemahan yang dihadapi industri kreatif produk sulam tempel bordir Desa Seritanjung adalah belum adanya kreatifitas dan inovasi produk, rendahnya pengetahuan megenai kewirausahaan serta belum adanya inovasi program pemasaran. 
Industri kreatif sulam tempel bordir di Desa Seritanjung belum mengalami proses kreatifitas dan inovasi. Desain produk juga tidak mengalami perubahan sedangkan lini produk masih berupa produk sprei, sarung bantal dan taplak meja padahal teknik sulam tempel bordir dapat diterapkan pada produk lain misalnya baju atau mukena. Program pemasaran masih belum efektif karena hanya memasarkan produk ke desa-desa yang berada di Kecamatan Kurungan Nyawa Kabupaten Ogan Komering Ulu secara personal selling.

Matriks EFE merupakan sarana analisis faktor eksternal yang tidak dapat dikendalikan. Identifikasi faktor peluang dan ancaman industri kreatif produk sulam tempel bordir Desa Seritanjung disajikan pada matriks EFE berikut ini.

\begin{tabular}{|c|c|c|c|}
\hline Faktor & Bobot & Rating & $\begin{array}{l}\text { Bobot } x \\
\text { Rating }\end{array}$ \\
\hline \multicolumn{4}{|l|}{ Peluang } \\
\hline 1.Pangsa pasar & 0,20 & 4 & 0,80 \\
\hline $\begin{array}{lll}\text { 2.Sikap } & \text { konsumerisme } & \text { pelanggan } \\
\text { potensial } & & \end{array}$ & 0,15 & 3 & 0,45 \\
\hline $\begin{array}{l}\text { 3.Kebijakan pemerintah terhadap } \\
\text { industri kreatif }\end{array}$ & 0,05 & 1 & 0,05 \\
\hline $\begin{array}{l}\text { 4.Kebijakan permodalan bank \& lembaga } \\
\text { keuangan bukan bank terhadap industri } \\
\text { kecil menengah }\end{array}$ & 0,05 & 1 & 0,05 \\
\hline 5.Akses kepada pelanggan & 0,05 & 2 & 0,10 \\
\hline Subtotal & 0,50 & & 1,45 \\
\hline \multicolumn{4}{|l|}{ Ancaman } \\
\hline $\begin{array}{l}\text { 1.Persaingan dengan produk sejenis } \\
\text { dalam } \\
\text { Desain }\end{array}$ & 0,10 & 1 & 0,10 \\
\hline $\begin{array}{l}\text { 2.Persaingan dengan produk sejenis } \\
\text { dalam } \\
\text { pilihan bahan baku }\end{array}$ & 0,10 & 1 & 0,10 \\
\hline $\begin{array}{l}\text { 3.Persaingan dengan produk sejenis } \\
\text { dalam } \\
\text { lini produk }\end{array}$ & 0,10 & 1 & 0,10 \\
\hline 4.Selera konsumen & 0,15 & 2 & 0,30 \\
\hline 5.Jumlah produksi pesaing & 0,05 & 4 & 0,20 \\
\hline Subtotal & 0,50 & & 0,80 \\
\hline Total & 1,0 & & 2,25 \\
\hline
\end{tabular}

Analisis faktor peluang yang dapat dimanfaatkan industri kreatif produk sulam tempel bordir Desa Seritanjung adalah pangsa pasar yang masih luas, sikap konsumerisme pelanggan potensial, kebijakan pemerintah terhadap industri kreatif, kebijakan bank dan lembaga bukan bank terhadap permodalan pada industri kecil serta akses kepada pelanggan. Saat ini, konsumen lebih suka membeli suatu produk daripada membuatnya yang sejalan dengan kemudahan akses untuk memperoleh produk baik dari sisi daya beli, harga maupun ketersediaan pasokan mengingat banyaknya pelaku usaha yang bergerak dalam bidang produk 
sejenis. Industri kreatif diakui keberadaannya dengan adanya kebijakan pemerintah mengenai industri kreatif yaitu melalui UndangUndang Nomor 3 Tahun 2014 tentang Perindustrian yang mendorong pengembangan industri kreatif nasional, Nomor 28 Tahun 2014 tentang Hak Cipta yang memberikan perlindungan kekayaan intelektual bagi karya kreatif dan Nomor 7 Tahun 2014 tentang Perdagangan yang mendorong perdagangan produk berbasis ekonomi kreatif. Keberpihakan bank dan lembaga keuangan bukan bank pada industri kecil dan menengah turut mendukung perkembangan industri kreatif dengan adanya unit usaha mikro dan UMKM (usaha menengah dan kecil menengah) melalui bunga kredit yang rendah dan pembayaran angsuran dalam jangka waktu yang cukup panjang. Unit-unit usaha tersebut beroperasi sampai dengan kota kecamatan yang relatif dekat dengan Desa Seritanjung. Akses menuju Desa Seritanjung mudah dan lancar karena didukung jalan raya yang baik dan jarak antara Desa Seritanjung dengan Kota Palembang hanya $\pm 60 \mathrm{~km}$ sedangkan di sisi lain Desa Seritanjung menjadi jalan alternatif propinsi menuju sebagai penyangga jalan nasional menuju Propinsi Lampung melalui Kabupaten Muara Enim, Ogan Komering Ulu atau Ogan Komering llir.

Analisis faktor ancaman yang dihadapi industri kreatif produk sulam tempel bordir Desa Seritanjung adalah persaingan dengan produk sejenis dalam desain produk, pilihan bahan baku, panjangnya lini produk, selera konsumen dan jumlah produksi pesaing. Pesaing produk mendesain produknya dengan kreatifitas dan mengikuti tren terbaru, memilih bahan baku yang tepat dengan masingmasing produk serta menambah lini produk sesuai perkembangan kebutuhan konsumen. Selera konsumen juga mudah dipengaruhi promosi karena keterbukaan informasi dan teknologi. Pesaing memproduksi secara massa sehingga ketersediaan produk pesaing terjamin dan harga per unit menjadi lebih rendah serta kualitas sesuai dengan standar yang diiklankan.

\section{Analisis Matriks SWOT}

Analisis matriks SWOT dilakukan setelah menyusun dan menganalisis matriks IFE dan EFE. Matriks ini dapat menjadi alat untuk merumuskan formulasi arah strategi usaha sehingga diperoleh beberapa alternatif strategi yang merupakan kombinasi faktor internal dan eksternal. Matriks SWOT biasa juga disebut matriks TOWS (threats, opportunities, weakness dan strenght). Anggraeni (2017) menjelaskan matriks TOWS adalah salah satu cara untuk mendapatkan alternatif strategi dengan cara menggabungkan masing-masing faktor yakni strategi SO (strenghtopportunities), strategi WO (weaknessopportunities), strategi ST (strengththreats) dan strategi WT (weaknessthreaths).

Strategi SO merupakan strategi yang memaksimalkan kekuatan agar memeproleh manfaat dari adanya peluang. Strategi SO adalah berbagai strategi yang dihasilkan dari suatu cara pandang bahwa perusahaan atau unit bisnis tertentu dapat menggunakan kekuatan yang mereka miliki guna memanfaatkan berbagai peluang (Solihin, 2012:170). Strategi SO yang dapat diterapkan pada industri kreatif produk sulam tempel bordir di Desa Seritanjung adalah mempertahankan ketersediaan tenaga terampil dengan memanfaatkan peluang kebijakan pemerintah mengenai industri kreatif. Selanjutnya, membangkitkan kembali 
produk sulam tempel bordir sebagai produk unggulan dengan memanfaatkan kemudahan akses kepada pelanggan, pangsa pasar yang luas dan sikap konsumerisme pelanggan potensial. Strategi SO lainnya adalah mempertahankan harga produk yang rendah dengan memanfaatkan kebijakan permodalan yang berpihak pada industri kecil menengah.

Strategi WO merupakan strategi yang meminimalkan kelemahan untuk memanfaatkan peluang dengan menjaga kehati-hatian dalam menangkap peluang. Strategi WO adalah berbagai strategi yang dihasilkan dari suatu cara pandang bahwa perusahaan atau unit bisnis tertentu dapat memanfaatkan berbagai peluang yang ada di lingkungan eksternal dengan cara mengatasi segala kelemahan sumber daya internal yang dimiliki perusahaan saat ini (Solihin, 2012:170). Strategi WO yang dapat diterapkan pada industri kreatif produk sulam tempel bordir di Desa Seritanjung adalah memanfaatkan pangsa pasar yang masih luas serta kemudahan dan kelancaran akses kepada pelanggan dengan memperbaiki program pemasaran yang kurang efektif, memanfaatkan sikap konsumerisme pelanggan potensial dengan membuat desain produk yang mengikuti tren atau menambah lini produk serta pemilihan bahan baku yang sesuai dengan jenis produk. Selanjutnya, memanfaatkan kebijakan pemerintah terhadap industri kreatif dengan bekerja sama dalam meningkatkan pengetahuan kewirausahaan serta memanfaatkan kebijakan permodalan yang berpihak pada industri kecil menengah untuk menjaga kontinuitas produksi.

Strategi ST adalah strategi yang menggunakan kekuatan untuk memperlunak ancaman dan menjadikannya peluang. Strategi ST adalah berbagai strategi yang dihasilkan dari suatu cara pandang bahwa perusahaan atau unit bisnis tertentu dengan menggunakan kekuatan yang dimiliki guna menghindari berbagai ancaman (Solihin, 2012:170). Strategi ST yang dapat diterapkan pada industri kreatif produk sulam tempel bordir di Desa Seritanjung adalah meningkatkan keterampilan tenaga kerja dalam bidang desain agar dapat berkompetisi dengan produk sejenis, meningkatkan kesadaran perajin dan pengusaha bahwa produk sulam tempel bordir pernah menjadi produk unggulan sehingga perajin dan pengusaha bersemangat untuk mengembalikan kondisi tersebut dengan memenangkan persaingan. Strategi ST selanjutnya adalah dapat membuat program pemasaran agar dapat mempengaruhi selera konsumen didukung oleh kreatifitas dan inovasi produk, mempertahankan harga per unit rendah sehingga dapat berkompetisi dengan pesaing yang memproduksi produknya secara massa.

Strategi WT adalah strategi bertahan yang meminimalkan kelemahan dengan membenahi sumber daya internal dan menghindari ancaman. Strategi WT adalah berbagai strategi yang bersifat bertahan serta bertujuan untuk meminimalisir semua kelemahan dan ancaman (Solihin, 2012:170). Strategi WT yang dapat diterapkan pada industri kreatif produk sulam tempel bordir di Desa Seritanjung adalah meningkatkan pengetahuan kewirausahaan agar dapat bersaing baik dalam desain produk, pemilihan bahan baku dan lini produk serta pengetahuan mengenai program pemasaran yang efektif dengan menggunakan seluruh 
program pemasaran yang mungkin dilakukan baik dalam aspek produk, promosi, harga maupun dalam aspek distribusi.

\section{Diagram Kartesius SWOT}

Matriks IFE industri kreatif sulam tempel bordir di Desa Seritanjung menghasilkan skor untuk faktor kekuatan sebesar 1,7 atau lebih besar dari faktor kelemahan 0,80 .sehingga diperoleh selisih sebesar 0,9. Matriks EFE industri kreatif sulam tempel bordir di Desa
Seritanjung menghasilkan skor untuk faktor peluang sebesar 1,45 atau lebih besar dari ancaman sebesar 0,80 sehingga diperoleh selisih sebesar 0,65 . Berdasarkan nilai skor tersebut dapat digambarkan diagram kartesius SWOT agar dapat ditentukan strategi yang tepat dalam upaya mengembangkan industri kreatif produk sulam tempel bordir di Desa Seritanjung Ogan Ilir. Berikut ini grafik kartesius SWOT industri sulam tempel bordir Desa Seritanjung.

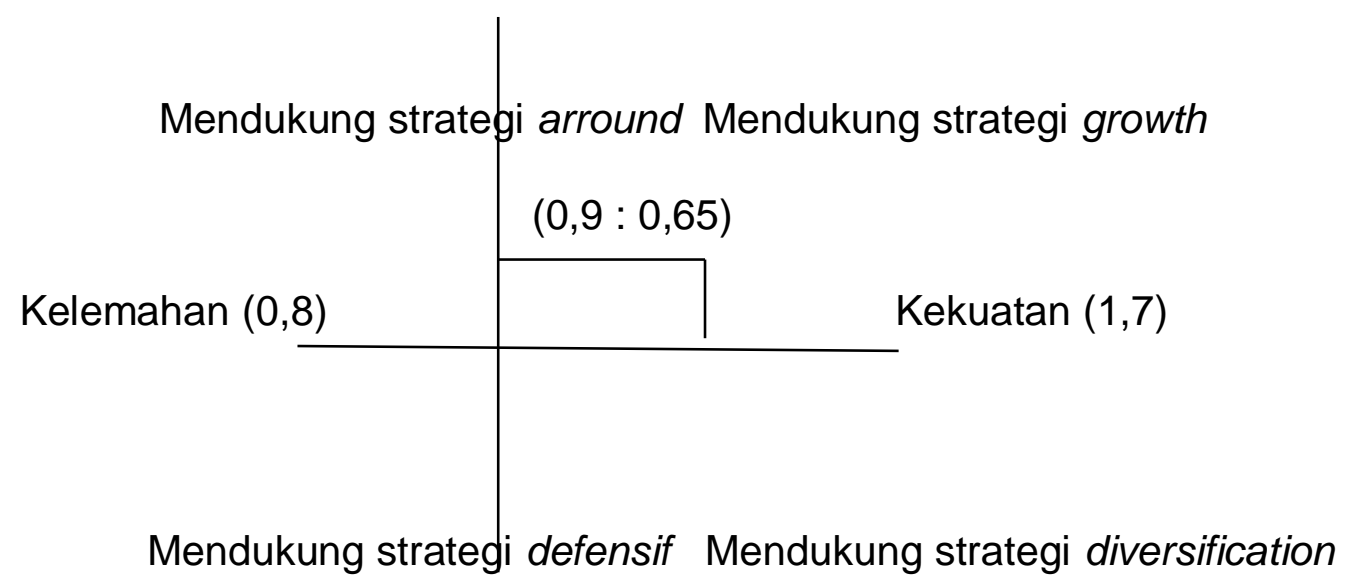

Ancaman $(0,8)$

Grafik kartesius memperlihatkan bahwa industri kreatif sulam tempel bordir berada pada kuadran I yang menunjukkan strategi SO atau strategi growth (pertumbuhan). Hal ini diperkuat dengan analisis pada tabel kombinasi strategi kuantitatif industri sulam tempel bordir berikut ini.

\begin{tabular}{|l|l|l|}
\hline \multirow{2}{*}{ EFE } & \multicolumn{2}{|c|}{ IFE } \\
\cline { 2 - 3 } & \multicolumn{1}{|c|}{ Kekuatan $(\mathrm{S})$} & \multicolumn{1}{|c|}{ Kelemahan $(\mathrm{W})$} \\
\hline Peluang $(\mathrm{O})$ & $\mathrm{S}+\mathrm{O}=1,7+1,45=3,15$ & $\mathrm{~W}+\mathrm{O}=0,8+1,45=2,25$ \\
\hline Ancaman $(\mathrm{T})$ & $\mathrm{S}+\mathrm{T}=1,7+0,8=2,5$ & $\mathrm{~W}+\mathrm{T}=0,8+0,8=1,6$ \\
\hline
\end{tabular}

Tabel kombinasi strategi kuantitaf menunjukkan akumulasi skor tertinggi pada strategi SO. Dengan demikian usulan strategi yang tepat untuk mengembangkan industri kreatif sulam tempel bordir adalah strategi SO yaitu dengan memanfaatkan semua kekuatan yang dimiliki untuk memperoleh semua peluang yang mungkin diraih sehingga industri kreatif sulam tempel bordir di Desa Seritanjung dapat tumbuh dan berkembang. 


\section{KESIMPULAN \\ Kesimpulan}

Faktor internal kekuatan yang dimiliki industri kreatif sulam tempel bordir di Desa Seritanjung adalah ketersediaan tenaga kerja yang terampil, produk sulam tempel bordir pernah menjadi produk unggulan dan khas, harga per unit produk relatif murah serta kebutuhan modal untuk produksi relatif rendah. Faktor internal kelemahan yang dihadapi industri kreatif sulam tempel bordir di Desa Seritanjung adalah yaitu belum adanya kreatifitas dan inovasi produk, rendahnya pengetahuan mengenai kewirausahaan serta belum adanya inovasi program pemasaran.

Faktor eksternal peluang yang dapat dimanfaatkan industri kreatif produk sulam tempel bordir Desa Seritanjung adalah pangsa pasar yang masih luas, sikap konsumerisme pelanggan potensial, kebijakan pemerintah terhadap industri kreatif, kebijakan bank dan lembaga bukan bank terhadap permodalan pada industri kecil serta akses kepada pelanggan. Faktor eksternal ancaman yang dihadapi industri kreatif produk sulam tempel bordir Desa Seritanjung adalah persaingan dengan produk sejenis dalam desain produk, pilihan bahan baku, panjangnya lini produk, selera konsumen yang mudah dipengaruhi pesaing dan pesaing melakukan produksi massa.

Usulan strategi yang tepat untuk mengembangkan industri kreatif sulam tempel bordir adalah strategi SO yaitu dengan mempertahankan ketersediaan tenaga terampil dengan memanfaatkan peluang kebijakan pemerintah mengenai industri kreatif, membangkitkan kembali produk sulam tempel bordir sebagai produk unggulan dengan memanfaatkan kemudahan akses kepada pelanggan, pangsa pasar yang luas dan sikap konsumerisme pelanggan potensial serta mempertahankan harga produk yang rendah dengan memanfaatkan kebijakan permodalan yang berpihak pada industri kecil menengah.

\section{DAFTAR PUSTAKA}

Anggraeni, Pratiwi, Sunarti, M. Kholid Mawardi. 2017. Analisis SWOT pada UMKM Keripik Tempe Amel Malang dalam Rangka Meningkatkan Daya Saing Perusahaan. Jurnal Administrasi Bisnis Vol. 43 No.1 Februari 2017 h. 104-114

Ayuningtyas, Riska Aprilia, Sri Hidayati Djoeffan. 2010. Strategi Pengembangan Pariwiasata di Sepanjang Sungai Kapuas Kota Pontianak. Jurnal Perencanaan Wilayah dan Kota. Vol.10 No. 1 Maret 2010 ISSN 14120690 h. 1-13

Gunawan, Yunus dan Adi Permadi. 2015. Strategi Pengembangan Industri Kecil Carica. Journal of Economics and Policy Vol. 8 No. 1 Maret 2015 h. 45-53

Handriani, Eka. 2011. Analisis Faktor Daya Saing di Kabupaten Semarang. Jurnal Dinamika Manajemen Vol. 2 No. 1 h. 17-25 ISSN 2086-0668 E-ISSN 23375434

Kamil, Ahmad. 2015. Industri Kreatif Indonesia:Pendekatan Analisis Kinerja Industri. Jurnal Media Trend Vol. 10 No. 2 Oktober 2015 h. 165-182 ISSN : 1858 - 1307 E-ISSN : $2460-7649$ 
Kementerian Perdagangan Republik Indonesia. 2008. Pengembangan Ekonomi Kreatif Indonesia 2025. Jakarta: Kementerian Perdagangan RI

Moleong, Lexy J. 2007. Metode Penelitian Kualitatif. Bandung:PT. Remaja Rosdakarya Offset.

Nisak, Zuhrotun. 2013. Analisis SWOT untuk Menentukan Strategi Kompetitif. Jurnal Ekbis Volume 9 Nomor 2 Tahun 2013

Rangkuti, Freddy. 2008. Analisis SWOT Teknik Membedah Kasus Bisnis. Jakarta:PT. Gramedia,Jakarta

Saputro, Alfredo Slamet, Kadarisman Hidayat, Edy Yulianto. 2016. Perencanaan Strategi Pemasaran Paket Data Kampus dalam Persaingan di Bidang Paket Data Internet (Studi Kasus pada PT. Telkomsel Cabang Malang). Jurnal Administrasi Bisnis Vol. 36 No. 1 Juli 2016 h.163-170

Siagian, Sondang P. 2005. Manajemen Stratejik, Jakarta:Bumi Aksara

Solihin, Ismail. 2012. Manajemen Stratejik. Jakarta:Penerbit Erlngga

Sugiyono. 2008. Metode Penelitian Bisnis. Bandung:Alfabeta

Sukirno, Sadono. 2010. Pengantar Teori Ekonomi Mikro. Jakarta:PT. Karya Grafindo Persada.

Tjiptono, Fandy dan Gregorius Chandra. 2008. Pemasaran Strategik. Yogyakarta:Penerbit Andi 